\title{
Conclusion: The Narrow Road to Martyrdom
}

\author{
Pierre-Antoine Fabre \\ École des hautes études en sciences sociales, Paris, France \\ pierre-antoine.fabre@ehess.fr
}

\begin{abstract}
The conclusion of this collection of studies endeavors to recapture five major questions that this special issue of the Journal ofJesuit Studies poses on the subject of martyrdom: Is this gesture a form of imitation of Christ (or imitatio Christi) or is it itself a sacrifice? How does it get rid of the shadow of suicide or voluntary death? How do the singularity of its experience and the community within which and in the name of which it is exercised articulate? Can martyrdom be defined as a renunciation of human love, and in this sense as the ultimate step in a process of conversion? How does martyrdom take its place in the writing of the religious history of the modern era, in particular, as far as the Society of Jesus is concerned, in the historiography of the nineteenth century? These five questions open this collection of essays to a field of research that remains to be pursued.
\end{abstract}

\section{Keywords}

martyrdom - sacrifice - suicide - conversion - Jesuit historiography - imitation of Christ

The studies collected in this volume are highly diverse in both subject and approach. Jean-Pascal Gay's essay sheds light on a theological definition of martyrdom earned by caring for plague victims in early seventeenth-century Europe. This new cause for canonization paved the way for the possibility of martyrdom in the here and now, unlike the martyr-missionaries in the "far-off Indies" or the ancient victims of persecutions buried in the catacombs of Rome. In keeping with research focusing on the attainment of holiness through martyrdom, Marie-Elizabeth Ducreux reveals the criteria 
that prompted the Habsburgs to promote a new form of Jesuit sanctity. The author demonstrates in particular that, in the period following the Thirty Years' War (1618-48), Jesuits chose not to advance causes for their confrères who had fallen victim to the massacres at the beginning of the conflagration, in Bohemia and Hungary. Instead, Jesuit saints were cast as the "peacemakers" of Europe (ad placandam Europam). Moreover, these Jesuit causes never appeared alone but were always part of a group of saints - a point to which I will return. Leonardo Cohen analyzes how the suffering endured by Catholic emissaries in the Kingdom of Ethiopia in the 16oos was experienced and presented as a martyrdom. Pierluigi Giovannucci, starting with an individual life story, the one of Anton Giulio Cesare Brignole (1605-62) recorded in a hagiographic account, highlights that a martyrdom the saint never sought and attempted to avoid stood out as a superior test in the conversion to a religious life. Finally, building on one of today's most fruitful lines of inquiry, Franco Motta and Eleonora Rai show that, because saints had to be freed from the limits of their religious affiliation, causes for Jesuit sainthood can be seen as a factor of continuity between the old and new Society of Jesus at the beginning of the nineteenth century, a time when this affiliation was in fact suppressed for the causes of Jesuit candidates.

This diversity speaks to the impact "holiness" has on theological, political, apostolic, and institutional spheres, without being reduced to any one of them. Indeed, this is probably one of the historical — even more than historiographical—strengths of this holiness.

The volume's diversity warrants a brief overview while engaging with five specific questions. The inquiry into martyrdom that we might call the casuistry of martyrdom, has raised the following questions over the span of its long history, which continue to intrigue us today:

1. Is martyrdom a form of imitating Christ (an imitatio Christi) or is it a sacrifice in and of itself?

2. How can it be distinguished from the specter of suicide or voluntary death?

3. How is the singularity of this experience articulated within the community in which and in whose name it is carried out?

4. What about martyrdom as renunciation of human love?

5. What about martyrdom as a writing of history?

These five questions define authentic martyrdom and lay the groundwork for establishing its concrete existence and demonstrable legitimacy. In this epilogue, I seek to show that these are also the same questions that, especially in the modern age, reveal other perspectives that allow martyrdom to evolve 
along with other ways of living a "Christian life," anchored in this life and the mundane world, as well as in the next life.

I focus on the early modern age because I believe that this age presents certain specific challenges in relation to martyrdom. On the one hand, the conditions for the acceptability of martyrdom were clarified in this period and made more selective to serve the growing jurisdictional nature of accessing holiness in Tridentine Catholicism. On the other hand, the stream of would-be martyrs swelled as evangelization campaigns expanded across the globe and a war of martyrs broke out in Europe in the wake of the Reformations and their specific martyrological creativity — two phenomena that were clearly interrelated. ${ }^{1}$

\section{Martyrdom and Sacrifice}

Here it is useful to recall that martyrdom had to legitimize itself quickly as an imitatio of Christ. Only Christ sacrificed himself - which explains why Christianity can be defined as a post-sacrificial religion that no longer offers sacrifices to God or gods because it is God who sacrifices himself. ${ }^{2}$ The reflexive pronoun is essential: he sacrifices himself in an act that already entails the possibility of survival because "he" lives on in the "self" of "self-sacrificing." For created beings, this survival or, more precisely, resurrection, can only take place at the "end of days." Martyrdom, therefore, imitates sacrifice: "We love martyrs," the Martyrdom of Polycarp reads, "as disciples and imitators of the Lord." ${ }^{3}$ The ambiguity of the formula used by Ignatius of Antioch (d. c.110) in his Letter to the Romans effectively expresses the difficulty of distinguishing martyrdom from sacrifice: "Plead to Christ for me that through the instrument of the wild beasts I may be considered a sacrifice for God." ${ }^{4}$ As can be seen in this passage, the author avoids affixing the pronoun to sacrifice, thereby

1 As I have previously argued, the rediscovery of the holy bodies in the Roman catacombs may have been part of this battle: see Pierre-Antoine Fabre, "Que cherchaient les jésuites de la fin du XVI ${ }^{\text {e }}$ siècle dans les catacombes?: Des anciens martyrs aux nouveaux saints," in Saints fondateurs à l'époque moderne, ed. Philippe Desmette and R. Dvriendt (forthcoming).

2 From the Passion of Perpetua: "The guard says to Felicita, who is giving birth in her prison, 'You who are suffering now, what will you do when you are in the presence of the beasts, whom you despised when you did not want to sacrifice?"' (Pierre Maraval, Actes et passions des martyrs chrétiens des premiers siècles [Paris: Cerf, 2010], 137; English translation: Angelina Zontine).

3 Martyrdom of Polycarp, 17.3, Sources chrétiennes (hereafter SC), 1obis:266 (English translation: Francis X. Glimm, The Apostolic Fathers [Washington, DC: Catholic University of America Press, 1947], 151-6o).

4 Ignatius of Antioch, Letter to the Romans, 4, 1-2, SC, 1obis:131 (English translation: Angelina Zontine). 
avoiding "self-sacrifice" and preserving the distinctive relationship between man and God.

This brings us to the Habsburgs' fervor for Ignatius of Loyola (c.1491-1556). We may think ourselves far from the early Christians and circus beasts, but the imitatio establishes a link. The 1656 Recueil des vertus de la Sérénissime princesse Anne Eléonore de Mantoue by Hermann Horst (160o-75) interprets the practice of Spiritual Exercises as a form of devotion to "saint Ignatius" (which is not at all obvious) and plays down the power of the imitatio, which replaced martyrdom without losing its origins. The Exercises of Ignatius defined imitatio Christi in the tradition of Thomas à Kempis (1380-1471), only to become in turn the object of an imitatio Ignatii. The devotions of Archduke Leopold Guillaume (1614-62) that Ducreux also describes completes this scaffolding: Leopold did the Exercises and had Daniello Bartoli's (1608-85) Vita Ignatii read to him on his deathbed.

Motta and Rai show that, during the Society's suppression, the act of imitatio Christi came to involve the entire Society of Jesus in the "martyrdom" of its persecution. It was a martyrdom that displayed all of the Society's virtues. Yet, it was also a martyrdom of carnal men and sinners, as observers such as Giulio Cesare Cordara (1704-85) later maintained when interpreting the suppression as a punishment suffered by an institution that had betrayed its origins. ${ }^{5}$ Whatever the interpretation, the suppression remained a martyrdom, and this is probably one of the reasons why — and reading Motta and Rai's article has convinced me of this - the restoration of the Society is so rarely referred to as a resurrection. Such a phrasing would have been tantamount to identifying with Christ himself, whereas it was only an imitatio Christi carried to the point of martyrdom (rather than "sacrifice").

The developments that Motta and Rai identify in the case of Andrzej Bobola (1591-1657) — a Polish Jesuit tortured by the Cossacks in 1657-add yet more weight to this reading: torture drives an identification with the Christ of the passion, ${ }^{6}$ moving through the stations of the cross to the highest stage possible.

5 Regarding the important figure of Cordara, see the recent research by Michela Catto, "La soppressione della Compagnia di Gesù di Giulio Cesare Cordara e le critiche a un secolo dalla rinascita," in La Compagnie de Jésus des Anciens Régimes au monde contemporain (XVIII-XX siècles), ed. Pierre-Antoine Fabre, Patrick Goujon, and Martín Morales (Rome: École française de Rome - IHSI, 2020), 543-54.

6 That is why the apologists of torture in contemporary Latin American pro-Catholic dictatorships have so relentlessly denied this possible identification, instead turning the victim of torture into someone whose body is unworthy of any humanity, that is, unworthy of Christ's humanity in suffering. On this topic, see the important book by William Cavanaugh, Torture and Eucharist: Theology, Politics, and the Body of Christ (Oxford: Blackwell, 1998) and the striking work by Michel de Certeau, "Luder: Linstitution de la pourriture" (1977), 
Torture is not yet the supreme sacrifice of the cross, but it is nearly equivalent to dying, and every moment in which Christ stand up again on the via crucis is in itself a virtual resurrection. ${ }^{7}$

\section{The Specter of Suicide}

A lengthy textual tradition-long predating the modern era-has pondered the thin line between self-sacrifice and suicide. To cite just one example, in the Stromata by Clement of Alexandria $\left(c .15^{\circ}-215\right)$, we read: "There are some, not belonging to us, but sharing our name merely, who are in haste to give themselves up, the poor wretches dying through hatred to the Creator."8 Does this mean that Christ committed suicide? This agonizing question is raised in numerous patristic writings. ${ }^{9}$ The long nighttime vigil at Gethsemane is the piece of the Gospel mosaic necessary to dispel this suspicion. Jesus did not wish to die and only God's will, expressed through him, led him to the sacrifice-like the volo of the mystics in Michel de Certeau's (1925-86) Fable mystique, or the irresistible desire to die in the Indies expressed in the indipetae letters.

Several articles in this volume focus on the tension between sacrifice and suicide. In his meticulous study of Théophile Raynaud's (1583-63) Martyrium per pestem (1630), Gay demonstrates that caring for the sick may earn the practitioner martyrdom if it leads to death because it involves a "risk" but not certain death (thus avoiding allegations of voluntary death). This practice later became instrumental in paving the way to martyrdom in peacetime Europe. ${ }^{10}$ Gay shows that this martyrdom also encourages probabilistic thinking, which explains why the Holy Office was wary of Raynaud's treatise. This relationship with risk threatened to upend the theological paradox of martyrdom as hoping for death without intentionally seeking it out. Raynaud's essay was eventually granted recognition in the name of defending a European martyrology (and

now republished in Histoire et psychanalyse entre science et fiction, ed. Luce Giard (Paris: Gallimard, 2nd ed. 2008), 255-77.

7 What Mel Gibson grasped in his famous and misunderstood film The Passion of the Christ (2004).

8 Clement of Alexandria, Stromata, 4.17.1, sC, 463:85.

9 Pierre-Emmanuel Dauzat has published a series of documents that are useful to frame this issue; see Le suicide du Christ (Paris: PUF, 1999).

10 In a text contemporaneous with Raynaud's essay, Jean-Baptiste Grillot reveals that François Bouton, a Jesuit who died in the plague of Lyon, "had received more consolation from this holy exercise than he had ever received in the East when he was in prison." 
with it, as Gay notes, a European theological and editorial "geography" rather than a merely Roman one). The essay was published during the generalate of Goswin Nickel (in office 1652-64) in a volume inspired by Raynaud's ideas, Heroes et victimae charitatis Societatis Iesu by Philippe Alegambe (1592-1652) and Janos Nadasi (1614-79), published in Rome in 1658. This belated recognition of Raynaud's work equally stemmed from the implicit connection between his conception of martyrdom and the de auxiliis controversy—briefly, the idea of freedom and grace cooperating to obtain salvation. Gay's work deftly reveals these various interconnections.

One of the key words and remedies against the temptation to commit suicide was "patience." This word allowed people to wait for death without any intention of rushing matters. It also made it possible, as Raynaud forcefully argued, to make the underlying principle of martyrdom the destiny of every Christian: patience includes suffering and endurance. It includes the death every Christian prepares for from birth, enduring life for the duration this preparation takes. It can even be argued that, as average longevity increased and old age became a bigger portion of life, the countless tales of martyrdom produced by Christian modernity are all parables of good death, of the ars moriendi, about which several prominent Jesuits, including Juan Alfonso de Polanco (1517-76) and Robert Bellarmine (1542-1621) wrote.

\section{The Martyr-Witness}

"Patience" is also at work in Cohen's paper. In this case, however, the essay's definition of martyrdom as patience is linked to another issue I believe to be fundamental, that of bearing witness. The Latin martyrium of course derives from the Greek martyr or witness, he or she who has seen. According to this first and tautological reading, martyr and witness are identified with each other and define each other. Here, I propose a second reading, in which the two terms are instead distinct from one another within the framework of the same scene. ${ }^{11}$ Martyrdom is singular in its fulfilment (grace touches only individuals) and simultaneously collective in its purpose (carried out in the name of a faith entrusted to a people). Martyrdom always has its own witness. This witness can be the one who testifies on behalf of an absent or missing witness- to

11 For a more in-depth analysis of this subject, see my "Vocation et martyre dans les Vocationes illustres," in Rivista storica italiana 132, no. 3 (2020): 1032-48, in which I focus on the concatenation between martyrdom, the narration of martyrdom, and the martyrdom of the author of the narration, focusing on a series of these Vocationes. 
reference two concepts of Paul Ricoeur (1913-2005). ${ }^{12}$ The longer the martyr must exercise patience and wait, the greater the number of potential places and moments during which martyrdom can be conveyed and passed on to the witness. I see this as a fundamental aspect of martyrdom and its accounts. Accounts are needed for the martyr to shine, and through them he or she gains legitimacy - so much so, in fact, that the value of the witness may even come close to replacing the value of martyrdom itself, consequently avoiding this martyrdom while building its glory.

Cohen's essay offers a telling illustration of this "double body" of the witness and martyr through the story of the suffering of Jesuit Diogo de Mattos (1588-1633) in the disastrous Ethiopian endeavor:

He endures [...] with such a joyful demeanor and with such a great spirit that he communicates them to everyone, captains and soldiers, even in the midst of battles and in the greatest of dangers [...]. He was so patient and never complained when he was injured [...]. He was deeply patient [italics mine].

\section{The Last Conversion}

We can consider all points above to be a description of the tools of a two-fold operation of promotion and rejection (but is it not true that the word "sacred" - from the Latin sacer-already expresses this?) of martyrdom in modern religious culture. ${ }^{13}$ Yet, I should also add an element that reappears throughout this special issue: martyrdom as a death to the world, this world, and the last conversion of a Christian life to the other world, that of eternal life. This statement contains two possible meanings: martyrdom is its ultimate fulfilment; but it is nothing more than this ultimate fulfilment, and consequently there is a series of additional stages representing martyrdom and which, in some way, may take its place. As Jean-Pascal Gay points out, martyrdom is nothing but the fulfilment of baptism-the first step to martyrdom and the hope of another life. Giovannucci shows, in turn, that the destiny of Anton Giulio Brignole Sale (1605-62) was marked by a series of conversions, first to religious life in general and then to the Society of Jesus in particular. Although

12 Paul Ricoeur, Oneself as Another, trans. Kathleen Blamey (Chicago: University of Chicago Press, 1994).

13 Here, I refer to an enlightening essay by Giorgio Agamben, Homo sacer: Sovereign Power and the Bare Life, trans. Daniel Heller-Roazen (Stanford, CA: Stanford University Press, 1998). 
Giovannucci does not explicitly point this out, probably because of the uncertainties surrounding this episode of Brignole's life, it is important for the purposes of my discussion to note that this two-part conversion was linked to his escape from a violent death when attacked by a Barbary ship while crossing the Mediterranean. According to this account, Brignole understood his vocation as lying beyond martyrdom. He believed he lived in an age of a "martyrdom of martyrdom," renouncing martyrdom and transforming it into a religious life that was devoted, like a slow death, to imitatio Christi-which, historically, played a key role in making martyrdom the normative ideal of an ordered life in the service of Christ.

\section{Writing History}

That brings us to the last vital finding of this collection, already suggested above in connection to witnessing: the significance of hagiographic - and especially martyrological-accounts in the historiography of the Society of Jesus. This special issue's contribution to this area should be placed in a more general framework.

One recent discovery about the history of the Society of Jesus is the Society's great historiographical silence in the nineteenth century. ${ }^{14}$ Prior to the early 190os, no member of the Society published writings on the history of the order, with the exception of a small number of responses to anti-Jesuit polemics by Edgar Quinet (1803-75) and the 1844 pamphlets by his colleague historian Jules Michelet (1798-74). Beginning in 1829 (only fifteen years after the 1814 restoration), the Society's leadership produced a series of decrees encouraging members to resume their historiographical work. In 1829, the XXI General Congregation (the numbering of the congregations skipped the suppression) "recommends that the fathers provincial collect the documents in their provinces and ensure that they be sent to Rome [...], especially for the period following the restoration of the Society [praecipue restituta Societate]." This decree reconfirmed Rome as the center of writing. It also established-although without specifying how - that only the history of the restored Society

14 Concerning this point, see Pierre-Antoine Fabre, "L'histoire de l"ancienne compagnie' à l'époque de la 'nouvelle compagnie': Perspectives de recherche," in Los jesuitas: Religión, política y educación (siglos XVI-XVIII), ed. José Martínez Millán, Henar Pizarro Llorente, and Esther Jiménez Pablo, 3 vols. (Madrid: Universidad Pontificia Comillas, 2012), 3:1795-1809; Pierre-Antoine Fabre and Patrick Goujon, Suppression et rétablissement de la Compagnie de Jésus (1773-1814) (Namur: Lessius, 2014). 
was to be written down. Subsequent events show that the histories that were eventually written at least partially circumvented Rome, and that the decree actually served to mask the lengthy paralysis plaguing the historiography of the Society. These two aspects are closely linked: They eventually led to the writing of universal histories, both a consequence and confirmation of Rome's centrality for the Society as an institution.

In his Memorias, Luis Martín (in office 1892-19o6) provides an account of the extremely long dormancy of the Society's historiography between its restoration and the end of the century, and I will not further expound on this point. As Martín writes: "One of the things that the last general congregation recommended to me most was the history of the Society, so often undertaken and promoted without success by some of my predecessors." ${ }^{15}$

How to make sense of this historiographical silence? One hypothesis is that the restored Society could not have written a history of the "old Society," from its foundation in 1540 to the suppression in 1773 , because it presented itself as the continuation of the old order, as asserted in the 1814 brief. How to qualify this past? This was a past that was not past, still firmly linked to the present and, in the early years of the restoration, often misunderstood and misconceived. It was a truly traumatic past of a Society that had been suppressed by the very person who had founded it, the Roman pontiff, in a sort of infanticide that haunted the new institution's memory and obsessively plagued its present.

The trials and hagiographies that historians use as sources are an exception to this silence, an imposing body of documentation recording the abundance of causes concluded in the nineteenth century. And yet—and this is the crucial point - the documentation includes causes that had been opened in the seventeenth century, reopened in the eighteenth century, only to be suspended and reopened again in the following century. The slow progression of these causes is thus the seemingly immobile site of continuity between the old and new Societies, between modern and contemporary ages, between the Protestant Reformation, the Enlightenment, and the restoration. Such apparent immobility was maintained by the subtle reprinting of hagiographic works, rewritten with discretion, and hewing close to the original. The extreme malleability of

15 See the recent annotated translation of his work: David G. Schultenover, S.J., ed. and transl., Jesuit Superior General Luis Martín García and His Memorias: "Showing Up" (Leiden: Brill, 2021). For further developments, see, among others, Pierre-Antoine Fabre and Gérard Neveu, "Rythmes de l'hagiographie: Le cas jésuite (Stanislas Kostka, Louis de Gonzague et Jean Berchmans)," in Procès de canonisation et hagiographie, ed. Philippe Castagnetti and Christian Renoux, forthcoming. 
the holy figures - their essential virtue and singular universality — lent itself to multiple reformulations that turned them, each with their own momentum, into men of their times.

Gay's trailblazing article moves in this direction, showing that the memory of martyrdom in the fight against the plague persisted well beyond the seventeenth century. In 1814 - the year the Society was restored - the epidemic that struck the Basque Country in the early 1800 s revived the theme of martyrium charitatis. As Gay writes, this "martyrium" survived the suppression and even contributed to the construction of the story of a Society that had allegedly remained unchanged since its birth.

Cohen shows, for his part, that the failure of the Jesuit endeavor in Ethiopia found the means for its transfiguration in the language of martyrdom - a risky enterprise suggesting that, if martyrdom transforms failure, then failure might just be another word for martyrdom. ${ }^{16}$

However, it is undoubtedly Motta and Rai's article that provides the most decisive contribution to this issue. Focusing in its latter part on the case of Francesco de Geronimo (1642-1716), the article shows that, during the period of suppression, the former Society of Jesus successfully promoted the cause of this late seventeenth-century Neapolitan Jesuit, and transformed the cause of one individual into that of the entire Society, in its martyrdom of suppression. Indeed, as mentioned above, this martyrdom succeeded to a large extent in bringing together divergent interpretations of the suppression of the Society. Once again, this was a way of dissolving and transforming martyrdom as such, turning the death of one individual who physically suffered for his faith into an allegory of another "body," the Society of Jesus that suffered in the mystical body of the church. The Society sought to use martyrdom as a means for its own underground survival as revolutions forever changed the world at large.

The cause of De Geronimo, opened in 1806, is all the more significant, not only because it connected the old Society to what would become the "new" Society, but also, and above all, because it evoked - almost reincarnated - the case of another visionary and missionary, a Neapolitan Jesuit, Giulio Mancinelli. Mancinelli lived from 1537 to 1618 and led a mission in the Ottoman empire. While the cause for his canonization was rapidly launched after his

16 On this point of view, I would like to refer to ongoing research, REVFAIL, conducted by JeanFrédéric Schaub and a group of European and Latin American historians, aiming to explore the meaning of the notion of failure in historiographic discourse. Many of these historians have reflected on the history of evangelization missions. I also participate by questioning the reasons why the first Jesuit mission, the 1541 mission in Ireland - an obvious failurenevertheless became a founding experience for centuries of Jesuit historiography. 
death, it eventually sank under the weight of Urban VIII's (1568-1644; r.163244) reform, never to resurface. ${ }^{17}$ De Geronimo's resemblance to Mancinelli is striking. Consider Motta and Rai's examples of the prophetic power of De Geronimo and his relationship with the "Turks."

To conclude, I would say that this special issue not only helps us understand the power of attraction sanctity holds over religious societies, but also introduces martyrdom into the history of the men and women of these societies, not as an exceptional event but as a normative ideal-in the sense of the Kantian formulation used above. Martyrdom regulates their ethical and civic lives: ethical and civic because it calls into question the greatest singularity in its relationship with what was once called and is now often once again known as the "common good."

17 On this lesser-known case, see Pierre-Antoine Fabre, "La misión como visión del mundo: Las autobiografías imaginarias de Giulio Mancinelli (1537-1618)," in Escrituras de la modernidad: Los jesuitas entre cultura retórica y cultura científica, ed. Perla Chinchilla and Antonella Romano (Mexico City: Universidad Iberoamericana, 2008), 177-206. 